\title{
Determinants of Access to Education and ICT in Nigeria
}

\author{
Isaac B. Oluwatayo ${ }^{1 *}$, Ayodeji O. Ojo ${ }^{2}$ \\ ${ }^{1}$ University of Limpopo, South Africa \\ ${ }^{2}$ University of Ibadan, Nigeria \\ isaacoluwatayo@yahoo.com*, ayodejiojo7591@gmail.com
}

\begin{abstract}
The world where development is driven by advancement in education and Information and Communication Technology (ICT) is fast emerging. This study therefore examined the determinants of access to education and ICT in Nigeria. The study used information from 4,508 households from the National Bureau of Statistics (NBS) General Household Survey (GHS) Data. Probit regression model and descriptive statistical tools were used to analyze relevant data. Analysis of the data showed that average household size was fairly large consisting of 7 members with majority (85.1percent) of the households headed by men. Average age of the household heads was 52 years while average years of education was 4 years. Also, 82.0percent and 61.2percent of the households in urban and rural Nigeria respectively had access to education. Therefore, inequality in access to education exists based on location. The factors influencing access to education in Nigeria were found to include age, gender, marital status and household size. The results also revealed age, years of education, marital status, gender and household size as determinants of access to ICT. Analysis of different ICT devices used in Nigeria showed that Radio (88.1percent), Mobile Phones (86.4percent) and Television (55.1percent) were the most widely used. Meanwhile, a significant difference exist in the factors influencing access to education and ICT in rural and urban Nigeria. The study therefore recommended increased investment in education and infrastructure. Government and private organizations should encourage gender equality in access to ICT through gender sensitive interventions.
\end{abstract}

Keywords: Access, Determinants, Education, ICTs, Households, Nigeria

\section{Introduction}

Background to the Study: Education is a veritable tool for the development of the capacity of citizens of any nation. Therefore, this underscores the reason human capital development occupies a central position in global policy discourse especially in the past one or two decades. Education is critical to the achievement of Sustainable Development Goals (SDGs) in Nigeria. This is because of the positive externalities of education on the society. Education provides the platform for households to gain employment and raise income towards reducing poverty and inequality. Again, educated households have been found to be more resilient to adverse shocks (UNDP, 2014). Specifically, the need to raise human capital stock of developing nations is underscored by the fourth SDG (SDG4). SDG 4 is to ensure inclusive and equitable quality education and promote life-long opportunities (UNESCO, 2014).The world is a global village where development is driven by advancement in education and Information and Communication Technology (ICT). Economic activities are now carried out on ICT platforms and competitiveness has heightened between countries. In the $21^{\text {st }}$ century, education and ICT are interrelated and interdependent ingredients of economic development. The ICT tools that are particularly useful in education include radio, television, mobile phones and computers (Aralu and Adetinmirin, 2014). Education is the process of transferring skills and information to an individual in order to increase his/her competencies. Meanwhile, ICT is the application of electronic devices for storing, processing and interpreting data into useful information. The application of ICT cuts across various sectors including education, security, tourism, agriculture, medicine and entertainment among others (Mokaya, 2012). The use of ICT is helping countries break barriers in development with regards to education and the economy. Therefore, we live in a world where many aspects of human life are driven by ICT (Idowu et al., 2008). ICT has presented opportunities to countries to expand production of goods and services as distance is no longer a barrier to trade. In the educational sector, books, videos and audio lecture materials that were hitherto herculean to access are just a click away.

Problem Statement: Nigeria is the most populous black nation in the world with a population of 174.5 million people (Odufuwa, 2012; Ademola et al., 2014). The youths of Nigeria account for the bulk of the Nigerian population. Therefore, the issue of education and ICT is critical to the achievement of meaningful national development. Nigeria has a large army of out-of-school children and young adults with limited 
literacy and numeracy skills. Again, less than 33 percent of basic school children usually proceed to senior secondary schools (US Embassy, 2012). There are reported cases of inequality in access to education along gender, geopolitical zones and even economic classes in Nigeria (Aja-Okorie, 2013; Andrew and Orodho, 2014; Humphreys and Crawford, 2014). The inequality in access to education based on geopolitical zones as reflected in non-school attendance among states in the North East and North West Zones of Nigeria is chronic rather than being episodic. For instance, 72 percent of primary school age children never attended school in Borno State (North East, Nigeria) compared to 3 percent in Southern Nigeria (US Embassy, 2012).

The indices of education and ICT in Nigeria are disturbing. An estimated 10 million out of the 30 million Nigerian children are not enrolled in school (US Embassy, 2012). Nigeria lags behind in the fight against illiteracy when compared with countries such as Brazil, Indonesia, Cuba, Poland and China. The literacy rate of Nigeria is low at 56.9 percent compared to 92 percent literacy rate in China, 90 percent in Indonesia and 89 percent in Brazil (Ishaq and Ali, 2014). Therefore, the reason Nigeria's performance in the achievement of Millennium Development Goals (MDGs) is not encouraging is not far-fetched. The level of utilization of ICT in Nigeria leaves more to be desired. This implies Nigeria has not fully harnessed ICT for broad-based growth. The low adoption of ICT in Nigeria can be linked to severe infrastructure deficits, widespread poverty, low awareness, exorbitant cost of accessing ICT and policy inconsistency regimes (Achimugu et al., 2009). Given the importance and problems of ICT and education, there are some questions begging for answers. Therefore, this study tried to provide answers to the following research questions:

- What are the drivers of access to ICT and education in Nigeria?

- Which region of the country has more access to ICT and education and why?

- What are the prominent ICT devices used in Nigeria?

Objectives of the Study: The broad objective of this study was to analyze the determinants of access to education and ICT among households in Nigeria. Specifically, this study tried to:

- Profile the socioeconomic characteristics of the households in the study area

- Analyze factors affecting access to education and ICT in the study area

- Identify and rank the type of ICT devices used among households in Nigeria

- Investigate the differences in the factors affecting access to education and ICT in rural and urban Nigeria.

Rationale for the Study: To the best of our knowledge, there has not been any published study that established the link between education and access to ICT in Nigeria based on empirical data. Therefore, this is a pioneer study that will identify the link between education and access to ICT. This study hopes to fill the gap in knowledge. The improvement in access to education and ICT is a very important developmental issue. While there are few studies on factors influencing access to education in Nigeria (Onwuameze, 2013; Ademola et al., 2014), several studies on the determinants of access to ICT in Nigeria exist (Obayelu and Ogunlade, 2006; Olatokun, 2009; Adomi and Kpangban, 2010) and these past attempts were not based on a nationally representative data. However, an exception is Onwuameze (2013) who used a nationally representative 2010 Nigeria Education Data Survey (NEDS).Therefore, this study used the NBS General Household Survey (GHS) data that was collected nationwide to investigate the factors influencing access to ICT and education in Nigeria as this study will serve as a building block for future studies while it contributes meaningfully to existing literature. There are many government interventions in the area of ICT and education in Nigeria with insignificant impact on the people. A recent example is that of the Osun State government that distributed 150, 000 free electronic tablets (opon-imo) in 2013 to secondary school students in order to promote e-learning (ICT based education) (Channelstv, 2013; OSSG, 2015). However, the performance of Osun State secondary school students in West African Senior School Certificate Examination (WASSCE) nosedived from 14 th position in 2009 to $24^{\text {th }}$ position in 2013 and staggered to $23^{\text {rd }}$ position in 2014 out of 36 states (Daily Post, 2014; Daily Independent, 2014). Therefore, the findings of this study will help policy makers make informed decisions on ICT and education in Nigeria. This study will provide information to policy makers on the factors influencing access to ICT and education in urban and rural Nigeria. These and many more underscores the importance of this study. 


\section{Literature Review}

Obayelu and Ogunlade (2006) studied the use of Information and Communication Technology for Gender Empowerment and Sustainable Poverty Alleviation in Nigeria. They used both secondary and primary data collected from 150 respondents in Kwara State, Nigeria. Obayelu and Ogunlade (2006) reported significant differences in access to ICT based on gender. They also found that ICT development in Kwara State, Nigeria is constrained by infrastructure deficits. Again, Olatokun (2009) investigated socio-demographic differences in access and use of ICTs in Nigeria. He collected primary data from 500 respondents in one urban (Bodija) and one rural (Erunmu) area in Ibadan, Oyo State, Nigeria. Olatokun (2009) used Chi-square statistics to determine the significant factors influencing people's access to ICT. He found gender, location (rural/ urban), income, age and education as factors influencing access to ICT in Nigeria. Also, Gillwald et al. (2010) carried out gender assessment of ICT access and usage in Africa. The study was carried out in 17 African countries. They found gender differences in access to ICT in Africa. They also reported employment status, education and income as factors influencing access to ICT. Gillwald et al. (2010) found that radio was the most commonly used ICT in Africa. Smits and Huisman (2012) investigated the determinants of educational participation and gender differences in education in six Arab countries-Algeria, Egypt, Morocco, Syria, Tunisia and Yemen. They used four-level multilevel logistic regression analysis to analyze the secondary data used for the study. They found that age, gender (girl), father's occupation, mother's employment status and living in rural areas were the determinants of access to education. Onwuameze (2013) carried out a study on the effects of social background, gender and regional factors on educational opportunity and inequality in Nigeria. She used secondary data from the 2010 Nigeria Education Data Survey (NEDS) for her study. Onwuameze (2013) found 53.6 percent and 42.1 percent of the respondents lack literacy and numeracy skills. She also reported household wealth, geographical region, religion and gender were correlates of literacy and numeracy in Nigeria. In their study on the socioeconomic factors influencing pupils' access to education in Informal settlements in Kibera, Nairobi County, Kenya, using primary data collected from 114 respondents, Andrew and Orodho (2014) found parents' education level, income and cost of education as factors influencing access to education in the study area.

\section{Methodology}

Scope of the Study: The study used secondary data from General Household Survey (GHS) collected by the National Bureau of Statistics in 2012/2013. The survey was carried out in the 36 states of Nigeria and the Federal Capital Territory (FCT). Data were collected at both urban and rural enumeration areas. The data provides information on education, ICT (including mobile phone, internet, television, radio and personal computer) and households' socioeconomic characteristics etc.

Analytical Techniques: In addressing the objectives of this study, descriptive statistics and the probit regression model were employed as analytical tools. While objectives 1 and 3 were analyzed using descriptive statistics such as frequency distribution tables, charts etc, objectives 2 and 4 were analyzed using probit regression model.

Model Specification: Probit model is a probabilistic model used to explain the behavior of a dichotomous variable (a variable that assumes the value of 0 or 1 ) with respect to a set of independent variables (Gujarati et al., 2012). Therefore, probit model was used to analyze the factors influencing access to education and access to ICT in Nigeria. The explicit form of the model is expressed as:

$Y_{i}=\beta_{0}+\beta_{1} X_{1}+\beta_{2} X_{2}+\beta_{3} X_{3}+\beta_{4} X_{4}+\ldots . . \beta_{n} X_{n}+\mu_{i}$

Where: $Y_{i}=$ Access to ICT (Personal Computer, Internet, Mobile Phone, Radio and Television) 1 for Yes, 0 for no access and access to education, 1 for Yes, 0 for no access

$\mathrm{X}_{1}-\mathrm{X}_{\mathrm{n}}$ are the independent variables

\section{Results and Discussion}

Socioeconomic Characteristics of Households in Nigeria: The result presented in tables 1 shows majority of the households are headed by males who are monogamously married. The average household size in Nigeria is large at 6 . The large household size could undermine households' access to ICT and education. 
Again, the average number of years of education is 4 . This shows that the households had considerably low level of education. The average age of the household heads in the pooled data is 52 years. This implies the household heads are still in the economically active periods of their lives. This corroborates the findings of Olatokun (2009); Gillwald et al. (2010) and Oluwatayo, (2014). Disaggregating by location, it was found that average household size in urban areas was lower at 6 compared to 7 in the rural areas. Meanwhile, the large household size constrains the access of rural households to ICT and education. Majority of the respondents in both urban and rural Nigeria were married with 4 years of education. This implies that the level of education is low and there is the need to improve on the existing level. The average age of household heads in urban Nigeria was 51years while the average in rural Nigeria was 52 years. This showed that the household heads were within the economically active periods of their lives.

Table 1: Socioeconomic Characteristics of the Respondents

\begin{tabular}{|c|c|c|c|}
\hline Variable & Pooled & Rural & Urban \\
\hline Household Size (mean) & $\begin{array}{l}6 \\
(3.21)\end{array}$ & $\begin{array}{l}7 \\
(3.23)\end{array}$ & $\begin{array}{l}6 \\
(3.06)\end{array}$ \\
\hline Age (mean) & $\begin{array}{l}52 \\
(14.83)\end{array}$ & $\begin{array}{l}52 \\
(15.06)\end{array}$ & $\begin{array}{l}51 \\
(3.71)\end{array}$ \\
\hline $\begin{array}{l}\text { Years of Education } \\
\text { (mean) }\end{array}$ & $\begin{array}{l}4 \\
(2.91)\end{array}$ & $\begin{array}{l}4.08 \\
(2.46)\end{array}$ & $\begin{array}{l}4.20 \\
(3.71)\end{array}$ \\
\hline Gender & $\begin{array}{l}\text { Male } 85.1 \% \\
\text { Female } 14.9 \%\end{array}$ & $\begin{array}{l}\text { Male } \quad 86.6 \% \\
\text { Female } 13.3 \%\end{array}$ & $\begin{array}{l}\text { Male } 81.9 \% \\
\text { Female } 18.1 \%\end{array}$ \\
\hline Marital Status & $\begin{array}{lr}\text { Married } & 81.5 \% \\
\text { Non-Married } & 14.9 \% \\
\end{array}$ & $\begin{array}{ll}\text { Married } & 83.3 \% \\
\text { Non-Married } & 16.7 \% \\
\end{array}$ & $\begin{array}{lc}\text { Married } & 77.4 \% \\
\text { Non-Married } & 14.9 \% \\
\end{array}$ \\
\hline
\end{tabular}

Determinants of Access to Education in Nigeria: The factors influencing household access to education are shown in Tables 2a. The log likelihood (-2639.21) of the fitted probit model shows the model is better than a model with no independent variables. This implies all the models are fit for the analysis.

Gender: There exists a negative and statistically significant relationship between gender and access to education in Nigeria (see Table 2). This implies that there is a difference in households' access to education based on gender. A further analysis, revealed a negative and statistically significant relationship between access to education and gender in rural and urban Nigeria. This is because of the differences in access to education based on gender considerations in Nigeria. This finding is consistent with the findings of Onwuameze (2013).

Age: The results presented in Table 2showed a negative and statistically significant relationship between age and access to education in pooled, rural and urban data. This implies that as an individual grows old the likelihood of having access to education decreases. In fact, a 1year increase in age of the household head will result in a decrease in the likelihood of the household to access education by 8 percent. Also, a 1 year increase in age will result in 7.3 percent and 8 percent decrease in the likelihood of households having access to education in rural and urban Nigeria respectively. This could be as a result of the time allocated to the various economic activities that the household heads are engaged in so as to cater for their households. This is consistent with the findings of Suryadarma and Suyahadi (2010) and Marcelo and Maria (2012).

Household Size: The result presented in Table 2 showed a negative and statistically significant relationship exists between household size and access to education. This implies a unit increase in household size will result in 0.5 percent decrease in the likelihood of the household having access to education. This is because as household size increases, the per capita expenditure increases and this could undermine household access to education. This corroborates the findings of Sackey (2007) and Donkoh and Amikuzumo (2011).

Marital Status: There exists a negative and statistically significant relationship between marital status and access to education (see Table 2) in urban areas of Nigeria. This could be because majority of the household heads are married and household size of married household heads is larger than that of the single household heads. This will have a negative impact on the per capita expenditure on the basket of goods and services consumed and available funds for education. 
Table 2: Factors Influencing Access to Education among Households in Nigeria

\begin{tabular}{|c|c|c|c|c|c|c|}
\hline Variable & Pooled & dy/dx & Rural & $\mathrm{dy} / \mathrm{dx}$ & Urban & $\mathrm{dy} / \mathrm{dx}$ \\
\hline Gender & $\begin{array}{l}-0.410^{* * *} \\
(0.000)\end{array}$ & -0.146 & $\begin{array}{l}-0.496 \\
(0.000)\end{array}$ & -0.189 & $\begin{array}{l}-0.478^{* * *} \\
(0.000)\end{array}$ & -0.107 \\
\hline Age & $\begin{array}{l}-0.022^{* * *} \\
(0.000)\end{array}$ & -0.008 & $\begin{array}{l}-0.192^{* * *} \\
(0.000)\end{array}$ & -0.107 & $\begin{array}{l}-0.035^{* * *} \\
(0.000)\end{array}$ & -0.008 \\
\hline Marital Status & $\begin{array}{l}-0.0140 \\
(0.359)\end{array}$ & -0.005 & $\begin{array}{l}0.020 \\
(0.346)\end{array}$ & -0.008 & $\begin{array}{l}-0.061^{* *} \\
(0.013)\end{array}$ & -0.015 \\
\hline $\begin{array}{l}\text { Household } \\
\text { Size } \\
\text { Diagnostics }\end{array}$ & $\begin{array}{l}-0.0139^{* *} \\
(0.033)\end{array}$ & -0.005 & $\begin{array}{l}-0.006 \\
(0.400)\end{array}$ & -0.002 & $\begin{array}{l}0.006 \\
(0.699)\end{array}$ & 0.001 \\
\hline $\begin{array}{l}\text { Log } \\
\text { Likelihood }\end{array}$ & -2639.21 & & -1962.71 & & -537.80 & \\
\hline $\begin{array}{l}\text { No of } \\
\text { Observations }\end{array}$ & 4508 & & 3099 & & 1409 & \\
\hline LR Chi2(4) & 394.99 & & 215.32 & & 250.92 & \\
\hline Prob $>$ Chi2 & $0.0000^{* * *}$ & & $0.0000^{* * *}$ & & $0.000^{* * *}$ & \\
\hline Pseudo $\mathrm{R}^{2}$ & 0.0696 & & 0.0520 & & 0.1892 & \\
\hline
\end{tabular}

Where, ${ }^{* * *}$ coefficients significant at 1 percent

** Coefficients significant at 5 percent

* Coefficients significant at 10 percent

Determinants of Access to Information and Communication Technologies (ICTs) in Nigeria: The determinants of household access to ICT are shown in Tables 3a, 3b and 3c. The log likelihood of the fitted probit models shows the models are better than models with no independent variables.

Years of Education: The results presented in Tables 3a reveals that there is a positive and statistically significant relationship between years of education and access to radio, television, personal computer and internet among households in Nigeria. This implies that a 1 year increase in the years of education will increase the likelihood of households to access television, radio, personal computer and internet by 4 percent, 4 percent, 1.2 percent and 1.0 percent respectively. This is not farfetched from the fact that educated people are able to operate computers and access internet and they use ICT (radio, television, computers and internet) more than their uneducated counterparts. This is consistent with the findings of Olatokun (2009) and Oluwatayo (2014).

Gender: A negative and statistically significant relationship exists between gender and access to radio; personal computer and internet in Nigeria (see Tables 3a). This implies gender differences in the access to personal computer, internet, radio and television among households in Nigeria. This corroborates the findings of Olatokun (2009) and Gillwald et al. (2010).

Age: There is a negative and statistically significant relationship between age and access to radio; television, personal computer and internet in Nigeria (see Table 3a). A unit increase in age will reduce the likelihood of households having access to radio, television, personal computer and internet. This is because young people are most active on ICT platforms and it reduces with age. This is in line with the findings of Olatokun (2009).

Household Size: There is a positive and statistically significant relationship between household size and access to radio and mobile phones in Nigeria (see Tables 3a). This could be because as household size increases, the number of working member of the household may increase thereby enhancing household per capita income and consequently access to mobile phones. Again, mobile phones and radio are cheaper to access compared to other ICT devices. However, a negative relationship exists between household size and access to internet among households in the pooled data. This could be because access to internet is low among households in Nigeria (see Table 4a). There is also a negative and statistically significant relationship between household size and access to personal computers in Nigeria. Similarly, there exists a negative relationship between access to Television and household size in Nigeria. This is substantiated by the findings of Oluwatayo (2014). 
Table 3a: Factors Influencing Access to ICT among Households in Nigeria (pooled data)

\begin{tabular}{|c|c|c|c|c|c|c|c|c|c|c|}
\hline Variable & Radio & $\mathrm{dy} / \mathrm{dx}$ & Television & $\mathrm{dy} / \mathrm{dx}$ & $\begin{array}{l}\text { Mobile } \\
\text { Phone }\end{array}$ & $d y / d x$ & $\begin{array}{l}\text { Personal } \\
\text { Computer }\end{array}$ & $\mathrm{dy} / \mathrm{dx}$ & Internet & $\mathrm{dy} / \mathrm{dx}$ \\
\hline Yrs of Edu & $\begin{array}{l}0.019 \\
(0.040)^{* *}\end{array}$ & 0.004 & $\begin{array}{l}0.024 \\
(0.000) * * *\end{array}$ & 0.004 & $\begin{array}{l}0.011 \\
(0.212)\end{array}$ & 0.002 & $\begin{array}{l}0.096 \\
(0.000)^{* * *}\end{array}$ & 0.012 & $\begin{array}{l}0.110 \\
(0.000)^{* * *}\end{array}$ & 0.010 \\
\hline Gender & $\begin{array}{l}-0.507 \\
(0.000)^{* * *}\end{array}$ & -0.096 & $\begin{array}{l}0.071 \\
(0.353)\end{array}$ & -0.096 & $\begin{array}{l}0.009 \\
(0.924)\end{array}$ & 0.002 & $\begin{array}{l}-0.356 \\
(0.004)^{* * *}\end{array}$ & -0.046 & $\begin{array}{l}-0.417 \\
(0.002)^{* * *}\end{array}$ & -0.036 \\
\hline Age & $\begin{array}{l}-0.006 \\
(0.001)^{* * *}\end{array}$ & -0.001 & $\begin{array}{l}-0.057 \\
(0.000)^{* * *}\end{array}$ & -0.001 & $\begin{array}{l}-0.015 \\
(0.000)^{* * *}\end{array}$ & -0.003 & $\begin{array}{l}-0.012 \\
(0.000)^{* * *}\end{array}$ & -0.002 & $\begin{array}{l}-0.020 \\
(0.000) * * *\end{array}$ & -0.002 \\
\hline $\begin{array}{l}\text { Marital } \\
\text { Status }\end{array}$ & $\begin{array}{l}-0.009 \\
(0.613)\end{array}$ & -0.002 & $\begin{array}{l}-0.009 \\
(0.525)\end{array}$ & $\begin{array}{l}- \\
0.0017\end{array}$ & $\begin{array}{l}0.007 \\
(0.684)\end{array}$ & 0.002 & $\begin{array}{l}0.007 \\
(0.719)\end{array}$ & 0.001 & $\begin{array}{l}0.030 \\
(0.169)\end{array}$ & 0.003 \\
\hline $\begin{array}{l}\text { Household } \\
\text { Size } \\
\text { Diagnostics }\end{array}$ & $\begin{array}{l}0.0185 \\
(0.028)^{* *}\end{array}$ & 0.004 & $\begin{array}{l}-0.016 \\
(0.012)^{* *}\end{array}$ & 0.0035 & $\begin{array}{l}0.029 \\
(0.000)^{* * *}\end{array}$ & 0.002 & $\begin{array}{l}-0.018 \\
(0.069)^{*}\end{array}$ & -0.002 & $\begin{array}{l}-0.038 \\
(0.001)^{* * *}\end{array}$ & -0.003 \\
\hline $\begin{array}{l}\text { Log } \\
\text { Likelihood }\end{array}$ & -1578.40 & & -3082.35 & & -1737.98 & & -1138.62 & & -853.09 & \\
\hline $\begin{array}{l}\text { No of } \\
\text { Observations }\end{array}$ & 4508 & & 4508 & & 4508 & & 4508 & & 4508 & \\
\hline LR Chi2 & 131.58 & & 37.28 & & 108.79 & & 193.72 & & 248.39 & \\
\hline Prob>Chi2 & $0.0000^{* * *}$ & & $0.0000^{* * *}$ & & $0.0000 * * *$ & & $0.0000^{* * *}$ & & $0.0000^{* * *}$ & \\
\hline Pseudo R ${ }^{2}$ & 0.0400 & & 0.0060 & & 0.0303 & & 0.0784 & & 0.1271 & \\
\hline
\end{tabular}

Where, ${ }^{* * *}$ coefficient significant at 1 percent

** coefficients significant at 5 percent

*coefficients significant at 10 percent

Years of Education: The results presented in Table $3 \mathrm{~b}$ show a positive and statistically significant relationship between years of education and access to television, personal computer and internet. A one year increase in the years of education will result in 0.9 percent, 0.6 percent and 0.3 percent increase in the likelihood of the household having access to television, personal computer and internet respectively. This is because educated people can operate and use ICT more than the uneducated ones. This finding corroborates the findings of Oluwatayo (2014).

Gender: There exists a negative and statistically significant relationship between gender and access to radio, personal computer and internet (see Table 3b). This is indicative of the gender differences in access to ICT in Nigeria. The society favors more men to have access to resources including ICT. This finding is consistent with the report of Olatokun (2009).

Age: There is a negative and statistically significant relationship between age of household head and access to radio; mobile phone, personal computer and internet in rural Nigeria (see Table 3b). This implies that a unit increase in the age of the household head will lead to a decrease in the likelihood of the households having access to radio, mobile phone, personal computer and internet by 0.1 percent, 1.3 percent, 0.9 percent and 1.6 percent respectively in rural Nigeria. This is because youths are more active on ICT platforms than older people.

Household Size: The results presented in Table $3 \mathrm{~b}$ show a positive and statistically significant relationship between household size and access to radio and mobile phone. In fact, a unit increase in household size will result in 0.8 percent and 0.01 percent increase in the likelihood of households having access to radio and mobile phones respectively. This is because majority of households have access to radio and mobile phones since they are the cheapest and the most common of the available ICT devices. However, a negative and statistically significant relationship exists between household size and access to personal computer and internet in rural Nigeria (see Table 3b). This is because access to personal computers is low among households in rural Nigeria. The low access could be due to high cost, low availability and high poverty level in rural Nigeria. This is consistent with the findings of Oluwatayo (2014). 
Table 3b: Factors Influencing Access to ICT among Rural Households in Nigeria

\begin{tabular}{|c|c|c|c|c|c|c|c|c|c|c|}
\hline Variable & Radio & $d y / d x$ & Television & dy/dx & $\begin{array}{l}\text { Mobile } \\
\text { Phone }\end{array}$ & $\mathrm{dy} / \mathrm{dx}$ & $\begin{array}{l}\text { Personal } \\
\text { Computer }\end{array}$ & $\mathrm{dy} / \mathrm{dx}$ & Internet & $d y / d x$ \\
\hline Yrs of Edu & $\begin{array}{l}0.0202 \\
(0.108)\end{array}$ & 0.004 & $\begin{array}{l}0.022^{* *} \\
(0.015)\end{array}$ & 0.009 & $\begin{array}{l}0.008 \\
(0.495)\end{array}$ & 0.002 & $\begin{array}{l}0.069 * * * \\
(0.000)\end{array}$ & 0.006 & $\begin{array}{l}0.074 * * * \\
(0.000)\end{array}$ & 0.003 \\
\hline Gender & $\begin{array}{l}-0.532^{* * *} \\
(0.000)\end{array}$ & -0.113 & $\begin{array}{l}0.144 \\
(0.165)\end{array}$ & 0.056 & $\begin{array}{l}-0.002 \\
(0.986)\end{array}$ & -0.003 & $\begin{array}{l}-0.491^{* *} \\
(0.014)\end{array}$ & -0.045 & $\begin{array}{l}-0.705^{* * *} \\
(0.008)\end{array}$ & -0.030 \\
\hline Age & $\begin{array}{l}-0.004 \\
(0.045)^{* *}\end{array}$ & -0.001 & $\begin{array}{l}-0.002 \\
(0.174)\end{array}$ & -0.001 & $\begin{array}{l}-0.013^{* * *} \\
(0.000)\end{array}$ & -0.006 & $\begin{array}{l}-0.009 * * * \\
(0.001)\end{array}$ & -0.001 & $\begin{array}{l}-0.016 * * * \\
(0.000)\end{array}$ & -0.001 \\
\hline $\begin{array}{l}\text { Marital } \\
\text { Status }\end{array}$ & $\begin{array}{l}-0.005 \\
(0.826)\end{array}$ & -0.001 & $\begin{array}{l}0.152 \\
(0.434)\end{array}$ & 0.006 & $\begin{array}{l}0.022 \\
(0.346)\end{array}$ & 0.006 & $\begin{array}{l}0.007 \\
(0.719)\end{array}$ & 0.001 & $\begin{array}{l}0.039 \\
(0.270)\end{array}$ & 0.002 \\
\hline $\begin{array}{l}\text { Household } \\
\text { Size } \\
\text { Diagnostics }\end{array}$ & $\begin{array}{l}0.036^{* * *} \\
(0.000)\end{array}$ & 0.008 & $\begin{array}{l}0.002 \\
(0.984)\end{array}$ & 0.0001 & $\begin{array}{l}0.043^{* * *} \\
(0.000)\end{array}$ & 0.011 & $\begin{array}{l}-0.026 * \\
(0.052)\end{array}$ & -0.002 & $\begin{array}{l}-0.049 * * * \\
(0.008)\end{array}$ & -0.002 \\
\hline $\begin{array}{l}\text { Log } \\
\text { Likelihood }\end{array}$ & -1195.71 & & -2101.14 & & -1414.68 & & -574.87 & & -337.41 & \\
\hline $\begin{array}{l}\text { No of } \\
\text { Observations }\end{array}$ & 3099 & & 3099 & & 3099 & & 3099 & & 3099 & \\
\hline $\begin{array}{l}\text { LR Chi2 } \\
\text { Prob>Chi2 } \\
\text { Pseudo R }{ }^{2}\end{array}$ & $\begin{array}{l}108.14 \\
\mathbf{0 . 0 0 0 0}^{* * *} \\
0.0433\end{array}$ & & $\begin{array}{l}15.72 \\
\mathbf{0 . 0 0 7} 7^{* * * *} \\
0.0037\end{array}$ & & $\begin{array}{l}89.84 \\
\mathbf{0 . 0 0 0 0 * * *} \\
0.0308\end{array}$ & & $\begin{array}{l}51.34 \\
\mathbf{0 . 0 0 0 0} \\
0.042 * *\end{array}$ & & $\begin{array}{l}60.91 \\
\mathbf{0 . 0 0 0 0} \\
0.08 * *\end{array}$ & \\
\hline
\end{tabular}

Where, ${ }^{* * *}$ coefficients significant at 1 percent

** coefficients significant at 5 percent

* coefficients significant at 10 percent

Table 3c: Factors Influencing Access to ICT among Urban Households in Nigeria

\begin{tabular}{|c|c|c|c|c|c|c|c|c|c|c|}
\hline Variable & Radio & dy/dx & Television & $d y / d x$ & $\begin{array}{l}\text { Mobile } \\
\text { Phone }\end{array}$ & $d y / d x$ & $\begin{array}{l}\text { Personal } \\
\text { Computer }\end{array}$ & dy/dx & Internet & $d y / d x$ \\
\hline Yrs of Edu & $\begin{array}{l}0.208 \\
(0.202)\end{array}$ & 0.003 & $\begin{array}{l}0.027 * * \\
(0.037)\end{array}$ & 0.006 & $\begin{array}{l}0.022 \\
(0.321)\end{array}$ & 0.001 & $\begin{array}{l}0.103^{* * *} \\
(0.000)\end{array}$ & 0.002 & $\begin{array}{l}0.114 * * * \\
(0.000)\end{array}$ & 0.019 \\
\hline Gender & $\begin{array}{l}-0.550 * * * \\
(0.000)\end{array}$ & -0.070 & $\begin{array}{l}-0.265^{* * *} \\
(0.036)\end{array}$ & -0.061 & $\begin{array}{l}-0.195 \\
(0.305)\end{array}$ & -0.013 & $\begin{array}{l}-0.305^{*} \\
(0.059)\end{array}$ & -0.061 & $\begin{array}{l}-0.326^{*} \\
(0.056)\end{array}$ & -0.054 \\
\hline Age & $\begin{array}{l}-0.010 * * * \\
(0.007)\end{array}$ & -0.001 & $\begin{array}{l}-0.018^{* * *} \\
(0.000)\end{array}$ & -0.004 & $\begin{array}{l}-0.021^{* * *} \\
(0.000)\end{array}$ & -0.001 & $\begin{array}{l}-0.017^{* * *} \\
(0.000)\end{array}$ & -0.003 & $\begin{array}{l}-0.025^{* * *} \\
(0.000)\end{array}$ & -0.004 \\
\hline $\begin{array}{l}\text { Marital } \\
\text { Status }\end{array}$ & $\begin{array}{l}-0.017 \\
(0.590)\end{array}$ & -0.002 & $\begin{array}{l}0.594^{* *} \\
(0.017)\end{array}$ & -0.014 & $\begin{array}{l}-0.033 \\
(0.391)\end{array}$ & -0.002 & $\begin{array}{l}0.008 \\
(0.768)\end{array}$ & 0.002 & $\begin{array}{l}0.022 \\
(0.433)\end{array}$ & 0.004 \\
\hline $\begin{array}{l}\text { Household } \\
\text { Size } \\
\text { Diagnostics }\end{array}$ & $\begin{array}{l}-0.009 \\
(0.587)\end{array}$ & -0.001 & $\begin{array}{l}0.022 \\
(0.136)\end{array}$ & 0.005 & $\begin{array}{l}0.046^{*} \\
(0.075)\end{array}$ & 0.003 & $\begin{array}{l}0.019 \\
(0.201)\end{array}$ & 0.021 & $\begin{array}{l}-0.001^{* * *} \\
(0.948)\end{array}$ & -.0002 \\
\hline $\begin{array}{l}\text { Log } \\
\text { Likelihood }\end{array}$ & $-351: 27$ & & -574.02 & & -210.49 & & -511.66 & & -445.33 & \\
\hline $\begin{array}{l}\text { No of } \\
\text { Observations }\end{array}$ & 1409 & & 1409 & & 1409 & & 1409 & & 1409 & \\
\hline LR Chi2 & 44.74 & & 99.41 & & 50.00 & & 134.94 & & 166.68 & \\
\hline Prob $>$ Chi2 & $0.0000 * * *$ & & $0.0000 * * *$ & & $0.0000 * * *$ & & $0.0000 * * *$ & & $0.0000 * * *$ & \\
\hline Pseudo $\mathrm{R}^{2}$ & 0.0599 & & 0.0797 & & 0.1062 & & 0.1165 & & 0.1576 & \\
\hline
\end{tabular}

Where, ${ }^{* * *}$ coefficients significant at 1 percent

** coefficients significant at 5 percent

* coefficients significant at 10 percent

Years of Education: There is a positive relationship between years of education and access to Television, personal computer and internet in urban Nigeria (see Table 3c). In fact, a 1 year increase in the years of education of the household heads will result in 0.6 percent, 0.2 percent and 1.9 percent increase in the likelihood of the household having access to television, personal computer and internet respectively in urban Nigeria. This is because the use of personal computer, internet and some televisions require basic literacy skills. This is consistent with the findings of Olatokun (2009).

Gender: The results presented in Table 3c depict a negative and statistically significant relationship between gender and access to radio, television, personal computer and internet. This implies that there are gender differences in access to ICT in urban Nigeria. 
Marital Status: The results presented in Table 3c show that a positive and statistically significant relationship exists between marital status and access to television in urban areas of Nigeria. This is because most of the respondents are married and more people have access to television in urban Nigeria (see Table $4 b)$.

Household Size: There is a positive and statistically significant relationship between household size and access to mobile phones in urban Nigeria (see Table 3c). This is because mobile phones are affordable and accessible compared to other ICT sources. However, a negative relationship exists between access to internet and household size in urban Nigeria.

The results presented in table 4 showed that the prominent ICT tools used in Nigeria were radio, mobile phones and television. However, majority of the households in Nigeria do not have access to internet and personal computer. Again, 67.7 percent of the household heads had access to education. This implies there is the need to increase access to education in Nigeria. Disaggregating the results by location we found access to education was higher in urban Nigeria (82.04 percent) than in rural Nigeria (61.15 percent). In terms of ICT, majority of the households in rural and urban Nigeria have access to radio and mobile phones. However, only 12.42 percent of the households in urban Nigeria had access to internet compared to 2.55 percent in rural Nigeria. In the same vein, access to personal computers was higher at 14.34 percent in urban Nigeria compared to 4.84 percent in rural Nigeria. This implies access to personal computer and internet is still very low in both urban and rural Nigeria. Again, a significant number of the households in urban Nigeria had access to television compared to their counterparts in rural Nigeria. In fact, 96.03 percent of the households in urban Nigeria had access to television while 57.92 percent of the households in rural Nigeria do not have access to television. This could be as a result of inadequate provision of social amenities like electricity and government neglect that characterize the rural areas of Nigeria. Inadequate access to schools and ICTs especially in rural Nigeria requires urgent attention because of the serious consequences on development.

Table 4: Distribution of Respondents by Access to Education and ICT

\begin{tabular}{llll}
\hline Variable & Pooled (\%) & Rural (\%) & Urban (\%) \\
\hline Access to Radio & & & \\
Yes & 88.10 & 86.09 & 92.55 \\
No & 11.90 & 13.91 & 7.45 \\
Access to Television & & & \\
Yes & 55.10 & 42.08 & 96.03 \\
No & 44.90 & 57.92 & 3.97 \\
Access to Internet & & & \\
Yes & 5.60 & 2.55 & 12.42 \\
No & 94.40 & 97.45 & 97.58 \\
Access to Mobile Phones & & & \\
Yes & & & \\
No & 86.40 & 82.03 & 96.03 \\
Access to Personal Computer & 13.60 & 13.97 & 3.97 \\
Yes & & & \\
No & & & \\
Access to Education (Have you ever & & 4.84 & 14.34 \\
attended school) & & 95.16 & 85.66 \\
Yes & 6.80 & & \\
No & 32.20 & 61.15 & 82.04 \\
\hline
\end{tabular}

Results presented in table 5 revealed radio, television and mobile phones are the most accessed ICT tools in rural and urban Nigeria. 
Table 5: Ranking of ICT accessed by Households in Urban and Rural Nigeria

\begin{tabular}{lllll}
\hline ICT Type & $\begin{array}{l}\text { Urban } \\
\text { Percentage }\end{array}$ & Rank & $\begin{array}{l}\text { Rural } \\
\text { Percentage }\end{array}$ & Rank \\
\hline Radio & 92.55 & $2^{\text {nd }}$ & 86.09 & $1^{\text {st }}$ \\
Television & 83.82 & $3^{\text {rd }}$ & 42.08 & $3^{\text {rd }}$ \\
Mobile Phone & 96.03 & $1^{\text {st }}$ & 82.03 & $2^{\text {nd }}$ \\
Personal Computer & 14.34 & $4^{\text {th }}$ & 4.84 & $4^{\text {th }}$ \\
Internet & 12.42 & $5^{\text {th }}$ & 2.55 & $5^{\text {th }}$ \\
\hline
\end{tabular}

\section{Conclusion and Recommendations}

The study examined the determinants of access to education and ICT among households in Nigeria. The average age of household heads was 52years with majority being monogamously married with average years of education being 4years. The study found radio, mobile phones and televisions to be the most commonly used ICT in Nigeria. The results of the probit model revealed age, gender, years of education, household size and marital status as the factors influencing access to ICT. The factors influencing access to education include age, gender, household size and marital status. There are differences in the effects of the factors influencing access to ICT and education based on location (rural and urban).In fact, while 82percent had access to education in urban Nigeriaa, only 61percent had access in rural Nigeria. Similarly, 96percent of the households in urban Nigeria had access to television compared to 42percent in rural Nigeria. These results allude to the fact that there are political considerations in the distribution of infrastructure facilities as they are highly skewed towards the urban areas in Nigeria. Meanwhile ICT and education are interrelated and interdependent hence the development of these sectors are critical to building the human capital stock of Nigeria. This is because the development of a country is inherent in the human capital stock of the nation.

Based on the findings of this study, the following are recommended:

- The government should increase and monitor investments in the educational sector especially in the rural areas to enhance ICT skills. The ICT skills will expose households to more economic opportunities and information. This will reduce the huge gap that exists between access to ICT and education among households based on location.

- Government and organized private sector should encourage gender equality in access to ICT through gender sensitive interventions. This will help remove gender inequality in access to ICT while Nigeria makes considerable progress in the achievement of SDGs.

- Government and multilateral organizations should intensify campaigns on family planning in Nigeria because the large household size obtainable in Nigeria undermines household access to education and ICT. This way, households will have children they can adequately train. Therefore, having moderate household size will help improve access to ICT and education among Nigerian households particularly in the rural areas

- Girl child education should be promoted by the society and government. Educating the girl child will improve the literacy level of Nigeria significantly because of the ripple effect. Also, the positive externality of training a girl child cannot be overemphasized especially in the area of household nutrition, health and education.

\section{References}

Achimugu, P., Oluwagbemi, O., Oluwaranti, A. \& Afolabi, B. (2009). Adoption of Information and Communication Technologies in Developing Countries: An Impact Analysis. Journal of Information Technology Impact, 9(1), 37-46.

Ademola, E. O., Ogundipe, A. T. \& Babatunde, W. T. (2014). Students' Enrolment into Tertiary Institutions in Nigeria: The influence of the Founders Reputation-A Case Study. Computing, Information Systems, Development, Informatics and Allied Research Journal, 5(3), 1-28.

Adomi, E. E. \& Kpangban, E. (2010). Application of ICTs in Nigerian Secondary Schools. Library Philosophy and Practice (e-journal), pp1-8. http://digitalcommons.unl.edu/libphilprac/345. 
Aja-Okorie, U. (2013). Women Education in Nigeria: Problems and Implications for Family Role and Stability. European Scientific Journal, 9(28), 1-11.

Andrew, S. L. \& Orodho, J. A. (2014). Socioeconomic Factors Influencing Pupils' Access to Education in Informal Settlements: A case of Kibera, Nairobi County, Kenya. International Journal of Education and Research, 2(3), 1-16.

Aralu, U. \& Adetimirin, A. (2014). Influence of Information Support System on ICT use by Distance Learners in University of Lagos, Nigeria. Journal of Information Engineering and Applications, 4(9), 1-7.

Channels Tv. (2013). Secondary School Students Get Free Computer Tablets in Osun retrieved from www.channelstv.com/2013/03/19/secondary-school-students-get-free-computer-tablets-in-osun/ on the $10^{\text {th }}$ of October, 2015.

Daily Independent. (2014). WAEC: Osun's Rating, a dent on Aregbesola's education policy retrieved from http://dailyindependentnig.com/2014/04/waec-osuns-rating-dent-aregbesolas-education-policyomisore/ on the $10^{\text {th }}$ of October, 2015.

Daily Post. (2014). 2014 WASSCE: Statistics show states with highest percentage pass, possible cause of mass failure retrieved from http://dailypost.ng/2014/08/29/2014-wassce-statistics-showstateshighestpercentage-pass-possible-cause-mass-failure/ on the $10^{\text {th }}$ October, 2015.

Donkoh, S. A. \& Amikuzumo, J. A. (2011). The Determinants of Household Education Expenditure in Ghana. Educational Research and Reviews, 6(8), 570-579.

Gillwald, A., Milek, A. \& Stork, C. (2010). Gender Assessment of ICT Access and Usage in Africa, Vol.1, Policy Paper No. 5, available at http://www.researchictafrica.net/publications/Towards_Evidencebased_ICT_Policy_and_Regulation_-

_Volume_1/RIA\%20Policy\%20Paper\%20Vol\%201\%20Paper\%205\%20-

\%20Gender\%20Assessment\%20of\%20ICT\%20Access\%20and\%20Usage\%20in\%20Africa\%202010 .pdf (accessed 9 September 2013)

Gujarati, D. N., Porter, D. C. \& Gunasekar, S. (2012). Basic Econometrics. Mc Grawhill Companies, $5^{\text {th }}$ Edition, pp594-599.

Humphreys, S. \& Crawford, L. (2014). Review of Literature on Basic Education in Nigeria: Issues of Access, Quality, Equity and Impact, pp1-20.

Idowu P., Cornford, D. \& Bastin, L. (2008). Health Informatics Deployment in Nigeria. Journal of Health Informatics in Developing Countries, 2(1), 15-24.

Ishaq, A. \& Ali, M. (2014). Non-Formal Education and the Girl-Child in Northern Nigeria: Issues and Strategies. Journal of Education and Practice, 5(37), 1-7.

Marcelo T. L. \& Maria, A. L. M. (2012). Determinants of Education Attainment and of the Millennium Development Goals in Honduras, pp1-25.

Mokaya, S. O. (2012). The Adoption of Information and Communication Technology by Small Enterprises in Thika Municipality, Kenya. International Journal of Business and Social Science, 3(13), 172-177.

Obayelu, A. E. \& Ogunlade, I. (2006). Analysis of the Uses of Information and Communication Technology for Gender Empowerment and Sustainable Empowerment and Sustainable Poverty Alleviation in Nigeria. International Journal of Education and Development Using Information and Communication Technology, 2(3), 45-69.

Odufuwa, F. (2012). What is happening in ICT in Nigeria? A Supply- and Demand-Side Analysis of the ICT sector. Research ICT Africa Policy Paper 6, pp1-54.

Olatokun, W. M. (2009). Analyzing Socio-Demographic Differences in Access and Use of ICTs in Nigeria using the Capability Approach. Journal of Issues in Informing Science and Information Technology, 6(1), 118.

Oluwatayo, I. B. (2014). Information and Communication Technologies as Drivers of Growth: Experience from Selected Small-scale Businesses in Rural Southwest Nigeria. Spanish Journal of Rural Development, 5(2), 65-77. DOI: 10.5261/2014.GEN2.06.

Onwuameze, N. C. (2013). Educational Opportunity and Inequality in Nigeria: Assessing Social Background, Gender and Regional Effects. A PhD thesis of the University of Iowa, pp1-190.

(OSSG) Osun State Government. (2015). 150, 000 e-learning tablets (opon-imo, tablet of knowledge) for Senior Secondary Schools retrieved from hhtp://osun.gov.ng/achievements/150, 000 e-learningtablets-opon-imo-tablet-of-knowledge-provided-for-senior-secondary-schools/ on $10^{\text {th }}$ October, 2015. 
Sackey, H. A. (2007). The Determinants of School Attendance and Attainment in Ghana: A Gender Perspective. African Economic Research Consortium Paper, 173, 1-40.

Smits, J. \& Huisman, J. (2012). Determinants of Educational Participation and Gender Differences in Education in Six Arab Countries. Nijmegen Center for Economics (NiCE) Working Paper, 12-102, 1-26.

Suryadarma, D. \& Suryahadi, A. (2010). Determinants of Education Attainment in Developing Countries: Can Higher Skills Compensate for Poverty? Pp1-19.

(UNDP) United Nations Development Program. (2014). Human Development Report: Sustaining Human Progress: Reducing Vulnerabilities and Building Resilience, UNDP, New York.

(UNESCO) United Nations Educational, Scientific and Cultural Organization. (2014). Sustainable Development Begins with Education: How education can contribute to post-2015 goals, pp1-24. 